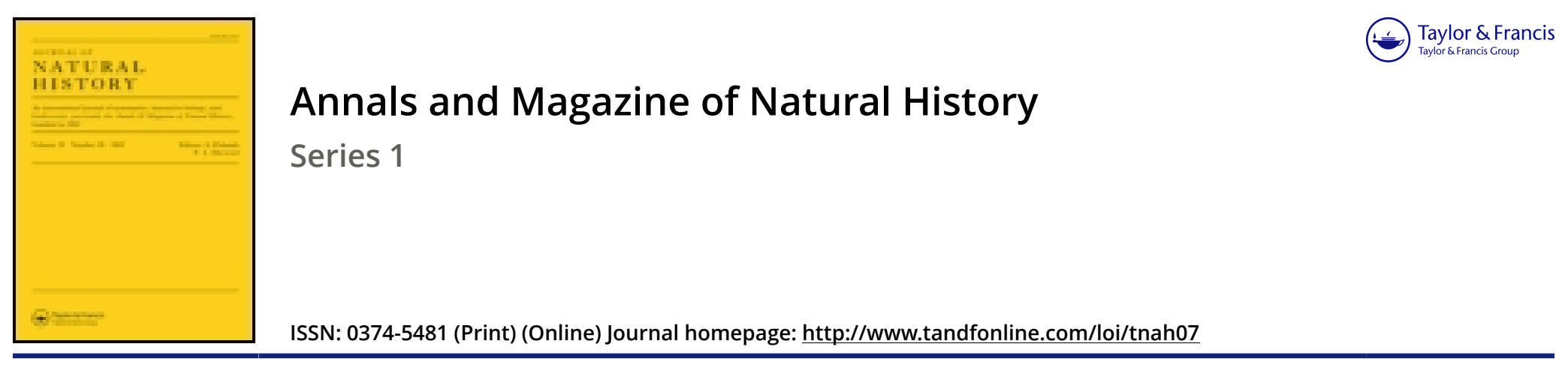

\title{
LII.-Generic characters of Gasterochisma melampus, a fish which inhabits Port Nicholson, New Zealand
}

John Richardson M.D. F.R.S.

To cite this article: John Richardson M.D. F.R.S. (1845) LII.-Generic characters of Gasterochisma melampus, a fish which inhabits Port Nicholson, New Zealand, Annals and Magazine of Natural History, 15:99, 346-346, DOI: 10.1080/037454809495339

To link to this article: http://dx.doi.org/10.1080/037454809495339

Published online: 17 Dec 2009.

Submit your article to this journal $₫$

View related articles ๔ 
to me this morning 21 inches long, in which the matured ova can be felt by pressure on the abdomen : I retain it thereforc uninjured. This almost brings the time up to the period when I obtained the ova last year, so that it would appear that from January to May, rather than at two distinet periods, these fishes deposit their ova.

LII.-Generic Characters of Gasterochisma melampus, a Fish which inhabits Port Nicholson, New Zealand. By Jонм RichARDson, M.D., F.R.S. \&c., Medical Inspector of Naval Hospitals at Haslar.

Piscis familiæ Scomberidarum.

Corpus valde compressum, clupeiforme. Cauda gracilis sine carinis. Venter acutus, alte diffissus et in vagina ejus pinnas ventrales thoracicas magnas recondens.

Linea lateralis inermis.

Pinnæ pectoris parvæ. Pinnæ dorsi contiguæ: prima spinis gracilibus membrana connexis instructa; secunda pinnaque ani pinnulis spuriis comitatæ. Pinna caudæ bifurca.

Anus parvus sub finem vaginæ ventralis latens.

Squamæ teneræ satis magnæ. Pectorale squameum nullum.

Dentes parvi setacei.

Radii membranæ branchiostegæ arctæ quinque.

Apertura branchialis ampla.

$O b s$. Species unica adhuc detecta Gasterochisma melampus in $\mathrm{Mu}$. seo Britannico hospitatur et a Domino Gray celeberrimo mihi benigne communicata. Nomen genericum fissuram ventris denotat.

\section{BIBLIOGRAPHICAL NOTICES.}

Recherches sur l'Embryogénie des Tubulaires, et l'Histoire naturelle des diffírens Genres de cette Famille qui habitent la cốte d'Ostende. Par P.-J. Van Beneden, Professeur à l'Université catholique de Louvain. (From the Mémoires de l'Académie Royale de Bruxelles. 4to. Pp. 72. Six Plates.)

THIS interesting essay supports the well-earned reputation of its distinguished author. It begins with a lucid and candid review of what had been previously done by other naturalists towards a history of the family ; a doubt of the correctness of some alleged fact being sometimes interposed, but more frequently the comment is made to reconcile observations which at first view are apparently contradictory and subversive of each other.

We can do little more than indicate the contents. The first chapter treats of the anatomy of the Tubularia. The tentacula are solid and composed of cells arranged somewhat after the pattern of the cellular tissue of vegetables. They are not organs of prehension as in the Hydre, but are probably subservient to respiration. In the Eudendrium they are the unly parts of the polyp which come into 